\title{
S100A6 Protein Expression is Different in Spitz Nevi and Melanomas
}

\author{
Adriana Ribé, M.D., Ph.D., N. Scott McNutt, M.D. \\ Dermatopathology Division, Department of Pathology, New York Presbyterian Hospital—Cornell \\ University Weill Medical College, New York, New York
}

The Spitz nevus is a benign melanocytic lesion that can be identified reliably in many cases by conventional histopathological criteria. However, there are subsets of Spitz nevi and of malignant melanoma that closely resemble each other and represent diagnostic challenges. S100 proteins are of interest because of their involvement in neoplastic processes and their genes are clustered in chromosome 1q21. Chromosome 1 contains mutations in several types of tumors, including melanomas. The expression of different $\mathrm{S} 100$ proteins (A2, A6 and A8/A9 or A12) was examined in 42 Spitz nevi, 105 melanomas, and 73 melanocytic nevi to test the hypothesis that their expression differs among these entities and may contribute to the distinction between these entities. The results showed an up-regulation of S100A6 protein in Spitz nevi, melanomas, and melanocytic nevi but with a different percentage of positivity and pattern of immunoreactivity. The differences between these three entities were statistically significant $(P<.001)$. All 42 Spitz nevi $(100 \%)$ showed strong and diffuse S100A6 protein expression, both in junctional and in dermal components of the nevi. Thirty-three percent of melanomas expressed S100A6 (35/105). The expression was mainly weak (30/35) and patchy in the dermal component and was negative or minimal in the junctional component. Fifty-six percent of different subtypes of melanocytic nevi (41/73) expressed S100A6, almost all of them weakly (40/41) and in the dermal component. Normal intraepidermal melanocytes were negative. The melanocytic cells in these three entities did not express S100A2, S100A8/A9 or A12. However, an up-regulation of S100A2 and S100A8/A9 or A12 proteins was observed in normal keratinocytes in the epidermis overlying Spitz nevi

Copyright () 2003 by The United States and Canadian Academy of Pathology, Inc.

VOL. 16, NO. 5, P. 505, 2003 Printed in the U.S.A.

Date of acceptance: January 24, 2003.

Address reprint requests to: N. Scott McNutt, M.D., Dermatopathology (F309), Weill Medical Center of Cornell University, 1300 York Avenue, New York, NY 10021; fax: 212-746-8570; e-mail: nsmcnutt@med.cornell.edu.

DOI: 10.1097/01.MP.0000071128.67149.FD and melanomas, without differences. In summary, a simple immunohistochemical test for S100A6 protein differentiated between Spitz nevi, melanomas, and melanocytic nevi. This marker could be used when the distinction is very difficult or controversial in routine studies, especially when there is a junctional component. Further molecular analyses of the S100A6 protein and gene should be performed to study the underlying genetic bases for such differences.

KEY WORDS: Melanocyte, Melanoma, S100, S100A6, Spindle and epithelioid cell nevus, Spitz nevus.

Mod Pathol 2003;16(5):505-511

The epithelioid and spindle cell nevus was first described in 1948 by Spitz and named juvenile melanoma (1). It is a benign melanocytic lesion found predominantly in children and adolescents and that can be identified reliably in many cases by previously well-described major and minor histopathological criteria (2-5). However, there are subsets of Spitz nevi and of malignant melanoma that closely resemble each other and represent diagnostic challenges. Additionally, some lesions are only partially excised (shave biopsies), thus often preventing the assessment of the lateral edges and deep components. The importance of distinguishing between these two entities lies in their different prognosis and treatment. Multiple studies using several approaches (immunohistochemistry, flow cytometry and molecular analysis) have been performed to identify potential differences between Spitz nevi and melanomas, but the results have been controversial or difficult to apply to routine material (6-38). S100 protein is not a single protein; instead there are a group of S100 proteins with diverse functions. The S100 protein family, a subclass of low molecular weight $\mathrm{Ca}^{2+}$-binding proteins, regulate a variety of cellular processes via interaction with different target proteins in a calcium-dependent manner. They are of interest because of their involvement in neoplastic pro- 
cesses and their genes are clustered in chromosome 1q21. Chromosome 1 is frequently altered in several tumors, including melanomas $(28,39,40)$. The most widely known commercially available antibody "anti-S100" mainly reacts with cells containing S100B polypeptide chains. This antibody was used as an early marker for melanocytic neoplasms and remains sensitive but not specific (41-43). Recently, monoclonal antibodies have become available that mainly react with S100aa and have identified several variants of the S100a chains (28). The expression of different S100 proteins (A2, A6, and A8/A9 or A12) was examined in Spitz nevi, melanomas, and melanocytic nevi cases to test the hypothesis that their expression differs among these entities and may contribute to the distinction between these entities.

\section{MATERIALS AND METHODS}

The cases were obtained from the files at the Dermatopathology Division of the New York Presbyterian Hospital-Cornell University Weill Medical College, between 1997 and 2002, based on the availability of adequate tissue material for study. Fortytwo cases of Spitz nevi, 105 cases of melanomas, and 73 cases of different types of melanocytic nevi were selected. The diagnosis was made on multiple H\&E routine-stained sections before this study. After review of newly cut routine microscopic sections, additional unstained sections were cut, deparaffinized, pretreated with pepsin $(0.25 \% \mathrm{w} / \mathrm{v}$, $\mathrm{pH}$ 2.0) for 5 minutes at $45^{\circ} \mathrm{C}$, and then reacted with the monoclonal antibodies: anti-S100A2, antiS100A6, MAC387, and HMB45 (Table 1). A streptavidin-alkaline phosphatase detection system with a red chromogen (Vector Lab) was used. The reaction time for the red chromogen was 20 minutes. Two investigators verified the results of the immunostains without references to the original diagnosis, although in some cases the diagnosis was obvious. The staining was evaluated semiquantitatively and read as positive (strong or weak) and negative. In the cases regarded as strongly positive, staining was observed in $>50 \%$ of the lesional cells whereas the weakly, positive cells were between 1 and $50 \%$ positive. The negative cases showed $<1 \%$

TABLE 1. Monoclonal Antibodies Used in this Study

\begin{tabular}{lllc}
\hline \multicolumn{1}{c}{ Antibody } & \multicolumn{1}{c}{ Clone } & Source & Dilution \\
\hline Anti-S-100A2 (S100L) & SH-L1 & Sigma & $1: 1000$ \\
$\begin{array}{l}\text { Anti-S-100A6 } \\
\text { (calcyclin) }\end{array}$ & CACY-100 & Sigma & $1: 1000$ \\
$\begin{array}{c}\text { Myeloid histiocyte } \\
\text { antigen }\end{array}$ & MAC387 & Dakopatts & $1: 100$ \\
$\begin{array}{l}\text { HMB45, } \\
\text { melanosome }\end{array}$ & HMB45 & DAKO & $1: 100$ \\
\hline
\end{tabular}

of positive lesional cells. Appropriate positive and negative controls were also included.

The $\chi^{2}$ test was used for comparison of groups. A $P$ value of $<.05$ was considered significant.

\section{RESULTS}

All Spitz nevi cases (42/42) strongly expressed S100A6 protein in a diffuse pattern, regardless of the subtype (compound, dermal, or junctional; Figs. 1, 2). The melanocytic cells in all Spitz nevi cases did not react with anti-S100A2 or MAC387 antibodies. However, the keratinocytes in the epidermis overlying Spitz nevi reacted with antiS100A2 antibody in some cells in the basal layer and with the MAC387 antibody in some cells in the upper third of the epidermis. The HMB45 antibody was weakly positive on the junctional component, whereas the dermal component usually was negative with only scattered positive cells.

S100A6 protein was expressed in 35 of 105 melanomas (33\%), 30 of them with weak positivity (86\%). The distribution of positive cases in the melanoma subtypes was as follows: 10 of 12 nodular (83\%), 3 of 7 metastatic (43\%), 16 of 54 superficial spreading (30\%), 2 of 7 lentigo maligna (28.5\%), 3 of 21 in situ (14\%), and 1 acral (Figs. 3, 4). Only 3 nodular melanomas and 1 superficial spreading and 1 acral melanoma were strongly positive. The expression in the positive melanoma cases was patchy throughout the tumor and negative or minimal in the junctional component. Three desmoplastic melanomas were negative. In all melanoma cases, the melanocytes did not stain with antiS100A2 or MAC387 antibodies. However, S100A2 protein was expressed in the keratinocytes located in the basal or parabasal layer of the epidermis adjacent to melanoma cells and MAC387 antibody was often observed in the full thickness of the overlying epidermis. HMB45 was positive in some of the

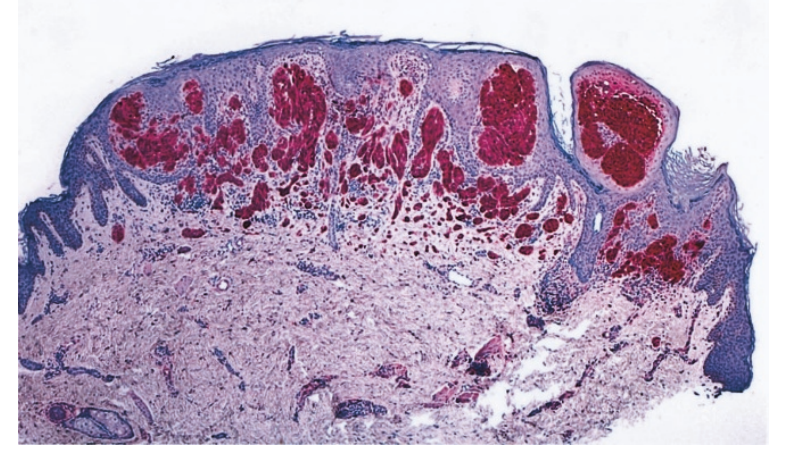

FIGURE 1. Spitz nevus. This photograph shows a strong and uniform reactivity with the monoclonal antibody against S100A6 protein in the nevus cells. 


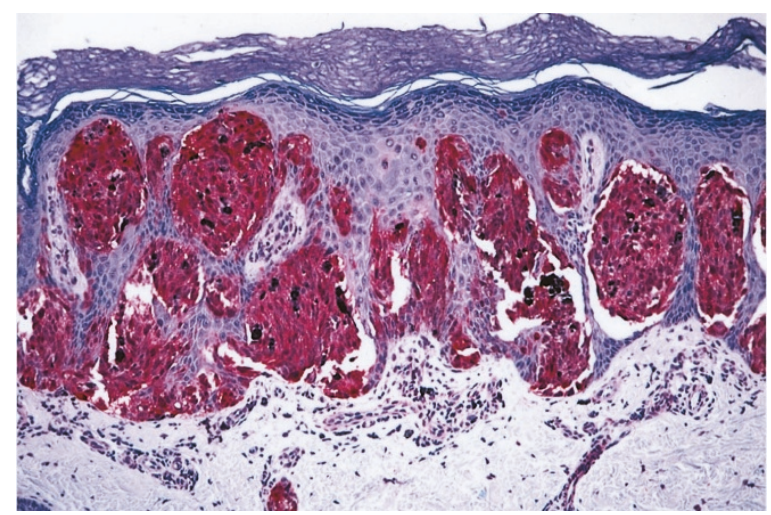

FIGURE 2. Spitz nevus. As in Figure 1, this photograph shows a strong and uniform reactivity with the monoclonal antibody against S100A6 protein in the nevus cells.

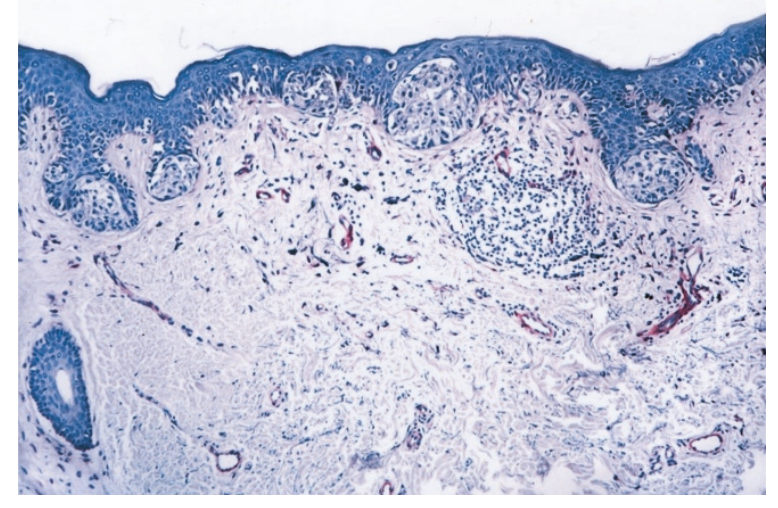

FIGURE 3. Melanoma in situ. The melanoma cells in the epidermis are negative for anti-S100A6 antibody. Some dermal dendrocytes and endothelial cells are positive, which represent internal positive controls for the adequacy of the reaction.

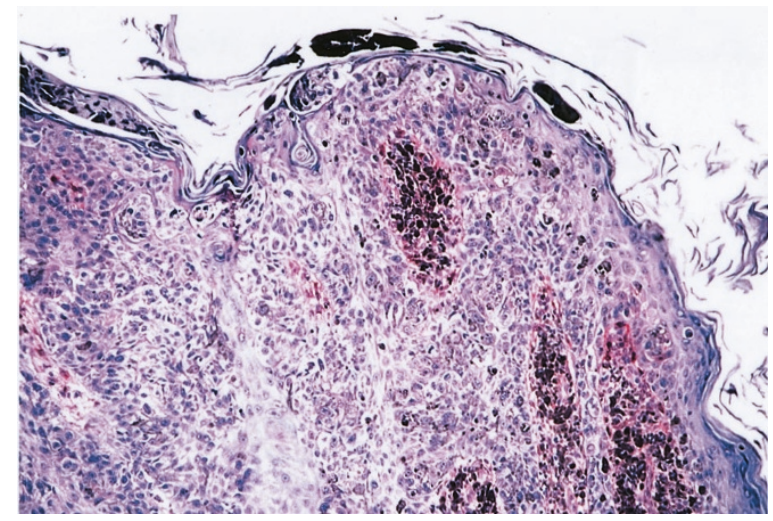

FIGURE 4. Melanoma, superficial spreading type. The melanoma cells in the epidermis and dermis are negative for anti-S100A6 antibody.

cells in the melanoma cases, except for the dermal component of the desmoplastic ones.

S100A6 protein was expressed in 41 of 73 melanocytic nevi (56\%), 40 of them with weak positivity (98\%). The distribution of positive cases in different melanocytic nevi was as follows: 22 of 25 nevus with architectural disorder (88\%), 6 of 12 combined nevi (50\%), 3 of 6 blue nevi (50\%), 5 of 13 compound nevi (38\%), 4 of 12 intradermal nevi (33\%), and 1 of 3 acral nevi (33\%; Fig. 5). Only 1 nevus with architectural disorder was strongly positive. The immunoreactivity in the positive cases was restricted to the deep dermal component. Two pigmented spindle cell nevi were negative. Neither anti-S100A2 nor MAC387 antibodies reacted with the nevus cells. However, anti-S100A2 and MAC387 antibodies were observed in a few cells in the basal and upper layers of the epidermis, respectively. HMB45 was positive in the junctional component of the nevi and in scattered nevus cells in the dermis. Blue nevi were strongly positive throughout.

The differences observed in the number of positive cells for anti-S100A6 antibody in Spitz nevi, melanomas, and melanocytic nevi cases were statistically significant, either comparing the three entities as whole groups $(P<.001)$ or comparing more similar histologic subgroups as junctional Spitz nevi-melanoma in situ $(P<.001)$ and Spitz nevinodular melanoma $(P<.001)$. S100A6 protein results are summarized in Tables 2-7.

\section{DISCUSSION}

Spitz nevus was first described by Spitz in a paper entitled "Melanomas of childhood" (1). Dr. Spitz (1) thought that these lesions were melanomas with an unusually good prognosis in children. Later, these "melanomas of childhood" or "benign juvenile melanomas" were renamed "spindle and epithelioid nevi" or "Spitz nevi" (reviewed by Elder and Murphy, 44). Pathologists' task of using routine light microscopy to differentiate between these Spitz nevi and melanomas has been difficult, sometimes leading to overdiagnosis of melanoma when the lesion is a Spitz nevus (leading to excessive surgery)

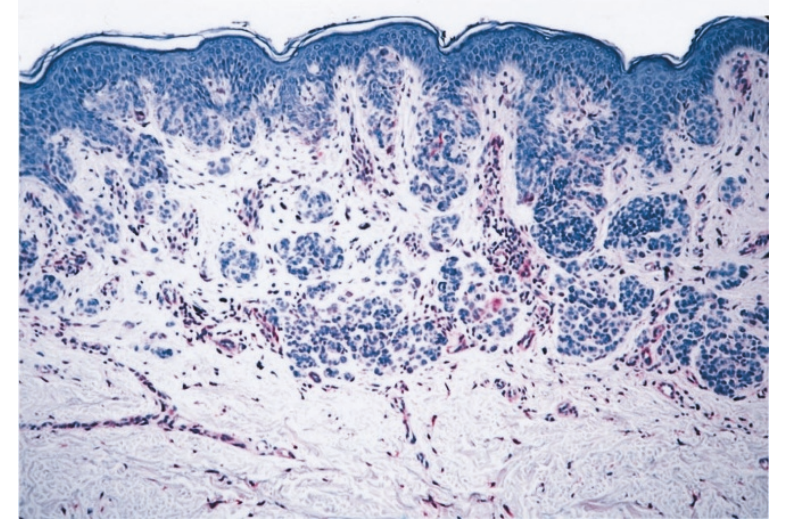

FIGURE 5. Melanocytic nevus with architectural disorder and atypia of melanocytes. The nevus cells are negative for anti-S100A6 antibody. Some dermal dendrocytes and endothelial cells are positive, which represent internal positive controls for the adequacy of the reaction. 
TABLE 2. Expression of S100A6 Protein in Spitz Nevi Cases

\begin{tabular}{|c|c|c|c|c|c|}
\hline \multirow{2}{*}{$\begin{array}{c}\text { Spitz Nevi } \\
\text { Cases }\end{array}$} & \multirow{2}{*}{$\begin{array}{c}\text { Number of } \\
\text { Cases }\end{array}$} & \multirow{2}{*}{$\begin{array}{c}\text { Number and \% of } \\
\text { S100A6 Positive } \\
\text { Cases }\end{array}$} & \multicolumn{3}{|c|}{ S100A6 Positive Cells } \\
\hline & & & $0 \%$ & $1-50 \%$ & $>50 \%$ \\
\hline Compound & 20 & $20 / 20(100 \%)$ & & & 20 \\
\hline Intradermal & 11 & $11 / 11(100 \%)$ & & & 11 \\
\hline Junctional & 11 & $11 / 11(100 \%)$ & & & 11 \\
\hline Total & 42 & $42 / 42(100 \%)$ & & & $42 / 42(100 \%)$ \\
\hline
\end{tabular}

TABLE 3. Expression of S100A6 Protein in Melanoma Cases

\begin{tabular}{|c|c|c|c|c|c|}
\hline \multirow{2}{*}{ Melanoma Cases } & \multirow{2}{*}{$\begin{array}{c}\text { Number of } \\
\text { Cases }\end{array}$} & \multirow{2}{*}{$\begin{array}{c}\text { Number and \% of } \\
\text { S100A6 Positive } \\
\text { Cases }\end{array}$} & \multicolumn{3}{|c|}{ S100A6 Positive Cells } \\
\hline & & & $0 \%$ & $1-50 \%$ & $>50 \%$ \\
\hline Superficial Spreading & 54 & $16 / 54(30 \%)$ & 38 & 15 & 1 \\
\hline In situ & 21 & $3 / 21(14 \%)$ & 18 & 3 & 0 \\
\hline Nodular & 12 & $10 / 12(83 \%)$ & 2 & 7 & 3 \\
\hline Lentigo maligna & 7 & $2 / 7(28.5 \%)$ & 5 & 2 & 0 \\
\hline Metastatic & 7 & $3 / 7$ (43\%) & 4 & 3 & 0 \\
\hline Desmoplastic & 3 & 0 & 3 & 0 & 0 \\
\hline Acral & 1 & $1 / 1(100 \%)$ & 0 & 0 & 1 \\
\hline Total & 105 & $35 / 105$ (33\%) & $70 / 105(67 \%)$ & $30 / 105(28.5 \%)$ & $5 / 105(5 \%)$ \\
\hline
\end{tabular}

TABLE 4. Expression of S100A6 Protein in Melanocytic Nevi Cases

\begin{tabular}{|c|c|c|c|c|c|}
\hline \multirow{2}{*}{ Melanocytic Nevi Cases } & \multirow{2}{*}{$\begin{array}{c}\text { Number of } \\
\text { Cases }\end{array}$} & \multirow{2}{*}{$\begin{array}{c}\text { Number and \% of } \\
\text { S100A6 Positive } \\
\text { Cases }\end{array}$} & \multicolumn{3}{|c|}{ S100A6 Positive Cells } \\
\hline & & & $0 \%$ & $1-50 \%$ & $>50 \%$ \\
\hline NAD & 25 & $22 / 25(88 \%)$ & 3 & 21 & 1 \\
\hline Compound & 13 & $5 / 13(38 \%)$ & 8 & 5 & 0 \\
\hline Predominantly intradermal & 12 & $4 / 12(33 \%)$ & 8 & 4 & 0 \\
\hline Combined & 12 & $6 / 12(50 \%)$ & 6 & 6 & 0 \\
\hline Blue & 6 & $3 / 6(50 \%)$ & 3 & 3 & 0 \\
\hline Acral & 3 & $1 / 3(33 \%)$ & 2 & 1 & 0 \\
\hline Pigmented spindle cell & 2 & 0 & 2 & 0 & 0 \\
\hline Total & 73 & $41 / 73(56.1 \%)$ & $32 / 73(44 \%)$ & $40 / 73(55 \%)$ & $1 / 73(1.3 \%)$ \\
\hline
\end{tabular}

$\mathrm{NAD}=$ nevus with architectural disorder and atypia of melanocytes

or to misdiagnosis as Spitz nevus when the lesion is in fact an invasive melanoma, with catastrophic consequences for the usually young patient. One of the cases described by Spitz (1) in her original series did in fact metastasize, illustrating the difficulty that even experts have in separating these lesions (1). The differentiation between Spitz nevus and melanoma remains problematic also as indicated by the number of slides sent for diagnostic consultation. The occasional failure of routine histopathology to separate adequately the cases of Spitz nevi from melanomas has been widely acknowledged and has led a group of authors to recommend complete excisions of Spitz nevi in adults just because of this uncertainty factor in diagnosis (45). Melanomas are increasing in the general population and often are being treated at less advanced stages than previously. In contrast to large melanomas, small ones present even greater difficulty in distinction from Spitz nevi $(46,47)$. These problems have led to a number of attempts to define useful adjunctive techniques to help in the distinction between Spitz nevus and melanoma. These techniques include the use of immunohistochemistry, flow cytometry, and nuclear morphometry, among others, and more recently, genetic analysis (6-38). Some of these techniques have been very cumbersome and are not readily adaptable to use for clinical diagnosis, which needs to be more rapid.

With the aim of contributing to the distinction between these two entities, the expression of the S100 protein subtypes (S100A2, A6, A8/A9/A12) was studied in Spitz nevi and melanomas as well as in melanocytic nevi. S100A6 (Calcyclin, CACY, 2A9, PRA, CaBP 5B10) can be induced by growth factors and has possible roles in the regulation of cell growth and division. It has been found in abundance in certain cancer cell lines and tumors, but is restricted to a specific subclass of cells in normal tissues (48-56). In the current study, S100A6 protein was strongly expressed in all Spitz nevi cases, suggesting that calcium-dependent signal transduction pathways may be abnormally regulated in these nevi. It was also present in the deep component of the compound, predominantly intradermal nevi and of nevi with architectural disorder, but with a weak and patchy staining. Although neuroid changes in ordinary melanocytic nevi expressed 
TABLE 5. Comparative S100A6 Expression

\begin{tabular}{lrrrr}
\hline & \multicolumn{4}{c}{ S100A6 Protein Expression } \\
\cline { 2 - 5 } & Spitz Nevi & Melanoma & $\begin{array}{c}\text { Melanocytic } \\
\text { Nevi }\end{array}$ & Total \\
\hline Negative & 0 & 70 & 32 & 102 \\
$>50 \%$ & 42 & 5 & 1 & 48 \\
$<50 \%$ & 0 & 30 & 40 & 70 \\
Total & 42 & 105 & 73 & 220 \\
\hline
\end{tabular}

Degrees of freedom: 4. Chi-square $=200.386136189636 . P$ is less than or equal to 0.001 .

TABLE 6. Comparative S100A6 Expression

\begin{tabular}{lccc}
\hline & \multicolumn{2}{c}{ S100A6 Protein Expression } \\
\cline { 2 - 4 } & Junctional Spitz & $\begin{array}{c}\text { In Situ } \\
\text { Nevi }\end{array}$ & Total \\
\hline Negative & 0 & 18 & 18 \\
$>50 \%$ & 11 & 0 & 11 \\
$<50 \%$ & 0 & 3 & 3 \\
Total & 11 & 21 & 32 \\
\hline
\end{tabular}

Degrees of freedom: 2 . Chi-square $=32 . P$ is less than or equal to 0.001 .

TABLE 7. Comparative S100A6 Expression

\begin{tabular}{lccr}
\hline & \multicolumn{3}{c}{ S100A6 Protein Expression } \\
\cline { 2 - 4 } & Spitz Nevi & $\begin{array}{c}\text { Nodular } \\
\text { Melanomas }\end{array}$ & Total \\
\hline Negative & 0 & 2 & 2 \\
$>50 \%$ & 42 & 3 & 45 \\
$<50 \%$ & 0 & 7 & 7 \\
Total & 42 & 12 & 54 \\
\hline
\end{tabular}

Degrees of freedom: 2 . Chi-square $=37.8 . P$ is less than or equal to 0.001 .

S100A6 protein (55), this reaction does not create problems in the differential diagnosis with Spitz nevus because these neuroid features are almost never described in them. Six of 12 combined nevi expressed S100A6 protein, mainly in a Spitz nevus component of the combined nevi. Interestingly, three of six blue nevi were weakly positive. Thirtythree percent of melanomas were anti-S100A6 positive. The positivity was mainly observed in the dermal component. The junctional component was negative or with scant positive cells. Low percentage positivity in the in situ, lentigo maligna, and superficial spreading subtypes contrasts with high percentage positivity in the nodular and metastatic subtypes of melanomas. Five of the nodular melanomas had spitzoid features. Nonetheless, the immunoreactivity was not as strong and uniform as in Spitz nevi. It has been previously reported that Type C nevus cells express S100A6 protein, supporting their terminal maturation along a pathway of schwannian differentiation (55). Sixty-six melanomas were negative for anti-S100A6. However, very undifferentiated or aggressive melanomas could express S100A6 protein again in progressive deregulation of gene expression similar to CEA expression in colon cancer.
Most of the melanoma cases of our study were primary melanomas and were anti-S100A6 negative. This negativity could result from a variety of changes, such as a mutation in a gene controlling S100A6 expression, a mutation deleting the immunogenic epitope detected by the monoclonal antibody, the expression of different S100A6 isoforms produced, or protein-protein binding blocking of the immunoreactive site, among other possibilities. Further molecular analyses of the S100A6 protein and gene should be performed in Spitz nevi, melanomas, and melanocytic nevi cases to study the underlying genetic bases for the differences observed. MAC387 antibody, long recognized as a nonspecific macrophage marker (57), has also been reported to react with keratinocytes related to cutaneous malignancies and melanocytic nevi (5861). We also observed MAC387 positivity in the keratinocytes overlying melanomas, melanocytic nevi, and Spitz nevi. The reaction was slightly stronger in melanomas and junctional Spitz nevi, comparing to other subtypes of Spitz nevi and melanocytic nevi, where it was weaker and uneven. Therefore, the use of MAC387 in this setting is noncontributory. Nevus and melanoma cells themselves were always negative with MAC387. S100A2 gene is down-regulated in some tumors and activated upon the interaction with wild-type p53; thus, it has been suggested that the S100A2 gene could act as a tumor suppressor-related gene (51). On the other hand, high expression of S100A2 protein has been reported in skin appendage tumors and in basal and squamous cell carcinomas (62). In our study, S100A2 protein expression was observed in the basal keratinocytes immediately adjacent to the nevus cell nests and to melanoma cells, without any significant difference between the cases. Nevus and melanoma cells did not express S100A2 protein.

In summary, we propose anti-S100A6 protein as a potential immunohistochemical marker that could be used diagnostically to distinguish Spitz nevus from melanoma, not only in classic cases but also in cases that are difficult to distinguish by routine microscopy. Moreover, the S100A6 expression in Spitz nevi suggests that calcium-dependent signal transduction pathways play an important role in regulating cellular processes in these nevi.

\section{REFERENCES}

1. Spitz S. Melanoma of childhood. Am J Pathol 1948;24:591609.

2. Allen AC, Spitz S. Malignant melanoma: a clinicopathological analysis of criteria for diagnosis and prognosis. Cancer 1953;6:1-45.

3. Reed RJ, Ichinose H, Clark WH, Mihm MC. Common and uncommon melanocytic nevi and borderline melanomas. Semin Oncol 1975;2:119-47. 
4. Paniago-Pereira C, Maize JC, Ackerman AB. Nevus of large spindle and/or epithelioid cells (Spitz nevus). Arch Dermatol 1978;14:1811-23.

5. Weedon D. Borderline melanocytic tumors. J Cutan Pathol 1985;12:266-70.

6. Gown AM, Vogel AM, Hoak D, Gough F, McNutt MA. Monoclonal antibodies specific for melanocytic tumors distinguish subpopulations of melanocytes. Am J Pathol 1986;123: 195-203.

7. LeBoit PE, Fletcher HV. A comparative study of Spitz nevus and nodular malignant melanoma using image analysis cytometry. J Invest Dermatol 1987;88:753-7.

8. Colombari R, Bonetti F, Zamboni G, Scarpa A, Marino F, Tomezzoli A. Distribution of melanoma specific antibody (HMB-45) in benign and malignant melanocytic tumors. Virchows Arch 1988;413:17-24.

9. Palazzo JP, Duray PH. Congenital agminated Spitz nevi: immunoreactivity with a melanoma-associated monoclonal antibody. J Cutan Pathol 1988;15:166-70.

10. Smoller BR, McNutt NS, Hsu A. HMB-45 recognizes stimulated melanocytes. J Cutan Pathol 1989;16:49-53.

11. Sun J, Morton TH Jr, Gown AM. Antibody HMB-45 identifies the cells of blue nevi. An immunohistochemical study on paraffin sections. Am J Surg Pathol 1990;14:748-51.

12. Skelton HGI, Smith KJ, Barrett TL, Lupton GP, Graham JH. HMB45 staining in benign and malignant melanocytic lesions. A reflection of cellular activation. Am J Dermatopathol 1991;13:543-50.

13. Soyer HP, Smolle J, Kerl H. Ki67 immunostaining in melanocytic skin tumors. Correlation with histologic parameters and prognostic significance. Am J Dermatopathol 1991;13: 196-7.

14. Wood WS, Tron VA. Analysis of HMB-45 immunoreactivity in common and cellular blue nevi. J Cutan Pathol 1991;18: 261-3.

15. Lazzaro B, Elder DE, Rebers A, Power L, Herlyn M, Menrad A, et al. Immunophenotyping of compound and Spitz nevi and vertical growth phase melanomas using a panel of monoclonal antibodies reactive in paraffin sections. J Invest Dermatol 1993;100:313s-7s.

16. Tu P, Miyauchi S, Miki Y. Proliferative activities in Spitz nevus compared with melanocytic nevus and malignant melanoma using expression of PCNA/cyclin and mitotic rate. Am J Dermatopathol 1993;15:311-4.

17. De Wit PE, Kerstens HM, Poddighe PJ, Van Muijen GN, Ruiter DJ. DNA in situ hybridization as a diagnostic tool in the discrimination of melanoma and Spitz naevus. J Pathol 1994;173:227-33.

18. Steiner A, Binder M, Mossbacher U, Wolff K, Pehamberger $\mathrm{H}$. Estimation of the volume-weighted mean nuclear volume discriminates Spitz's nevi from nodular malignant melanomas. Lab Invest 1994;70:381-5.

19. Thompson CT. Cytogenetics of cutaneous malignant melanoma. In: LeBoit PE, editor. Pathology: state of arts review. Malignant melanoma and melanocytic neoplasms. 1st ed. Philadelphia: Hanley and Belfus; 1994. p. 401-12.

20. McNutt NS, Urmacher C, Hakimian J, Hoss DM, Lugo J. Nevoid maligna melanoma: morphologic patterns and immunohistochemical reactivity. J Cutan Pathol 1995;22:50217.

21. Penneys N, Seigfried E, Nahass G, Vogler C. Expression of proliferating cell nuclear antigen in Spitz nevus. J Am Acad Dermatol 1995;32:964-7.

22. Smolle J, Hofmann-Wellenhof R, Soyer HP. Approach to diagnostic image analysis of melanocytic tumors. J Cutan Pathol 1995;22:128-31.

23. Bergman R, Sabo E, Schafer I. Measurement of the maturation parameter by using computer-assisted interactive image analysis may be helpful in the differential diagnosis between compound Spitz nevus and malignant melanoma. Am J Dermatopathol 1996;18:567-70.

24. Lee CS, Pirdas A, Lee MW. Immunohistochemical demonstration of the nm23-H1 gene product in human malignant melanoma and Spitz nevi. Pathology 1996;28:220-4.

25. Vogt T, Stolz W, Glabl A, Abmayr W, Hohenleutner U, Schmoeckel C, et al. Multivariate DNA cytometry discriminates between Spitz nevi and malignant melanomas because large polymorphic nuclei in Spitz are not aneuploid. Am J Dermatol 1996;18:142-50.

26. Bergman R, Lurie $M$, Kerner H, Killim S, FriedmanBirnbaum R. Mode of c-myc protein expression in Spitz nevi, common melanocytic nevi and malignant melanomas. J Cutan Pathol 1997;24:219-22.

27. Prieto VG, Woodruff JM. Expression of HMB45 antigen in spindle cell melanoma. J Cutan Pathol 1997;24:580-1.

28. McNutt NS. The S100 family of multipurpose calciumbinding proteins. J Cutan Pathol 1998;25:521-9.

29. Bastian BC, Le Boit PE, Pinkel D. Mutations and copy number increase of HRAS in Spitz nevi with distinctive histopathological features. Am J Pathol 2000;157:967-72.

30. Nagasaka T, Lai R, Medeiros LJ, Brynes RK, McCourty A, Harada T, et al. Cyclin D1 overexpression in Spitz nevi: an immunohistochemical study. Am J Dermatopathol 1999;21: 115-20.

31. Sprecher E, Bergman R, Meilick A, Kerner H, Manov L, Reiter I, et al. Apoptosis, Fas and Fas-ligand expression in melanocytic tumors. J Cutan Pathol 1999;26:72-7.

32. Wettengel GV, Draeger J, Kiesewetter F, Schell H, Neubauer S, Gebhart E. Differentiation between Spitz nevi and malignant melanoma by interphase fluorescence in situ hybridization. Int J Oncol 1999;14:1177-83.

33. Bastian BC, Wesselmann U, Pinkel D, Le Boit P. Molecular cytogenetic analysis of Spitz nevi shows clear differences to melanoma. J Invest Dermatol 1999;113:1065-9.

34. Bergman R, Azzam H, Sprecher E, Manov L, Munichor M, Friedman-Birnbaum R, et al. A comparative immunohistochemical study of MART-1 expression in Spitz nevi, ordinary melanocytic nevi, and malignant melanomas. J Am Acad Dermatol 2000;42:496-500.

35. Evans MJ, Sanders DS, Grant JH, Blessing K. Expression of Melan-A in Spitz, pigmented spindle cell nevi, and congenital nevi: comparative immunohistochemical study. Pediatr Dev Pathol 2000;3:36-9.

36. Ruhoy SM, Prieto VG, Eliason SL, Grichnik JM, Burchette JL, Shea CR. Malignant melanoma with paradoxical maturation. Am J Surg Pathol 2000;24:1600-14.

37. Tosi P, Miracco C, Santopietro R, Pacenti L, Perotti R, Materno M, et al. Possible diagnostic role of telomerase activity in the differential diagnosis between Spitz naevi and cutaneous malignant melanoma. Br J Dermatol 2000;142:1060-1.

38. Harvell JD, Bastian BC, LeBoit PE. Persistent (recurrent) Spitz nevi: a histopathologic, immunohistochemical, and molecular pathologic study of 22 cases. Am J Surg Pathol 2002;26:654-61.

39. Zimmer DB, Cornwall EH, Landar A, Song W. The S100 protein family: history, function and expression. Brain Res Bull 1995;37:417-29.

40. Schafer BW, Heizmann CW. The S100 family of EF-hand calcium-binding proteins: functions and pathology. Trends Biochem Sci 1996;21:134-40.

41. Cochran AJ, Wen DR, Herschman HR, Gaynor RB. Detection of S-100 protein as an aid to the identification of melanocytic tumors. Int J Cancer 1982;15:295-7.

42. Nakajima T, Watanabe S, Sato Y, Kameya T, Shimosato Y, Ishihara K. Immunohistochemical demonstration of S100 protein in malignant melanoma and pigmented nevus, and its diagnostic application. Cancer 1982;50:912-8. 
43. Gaynor R, Herschman HR, Irie R, Jones P, Morton D, Cochran A. S100 protein: a marker for human malignant melanomas? Lancet 1981;1:869-71.

44. Elder DE, Murphy GF, editors. Melanocytic tumors of the skin. Atlas of tumor pathology. 3rd series. Washington, D.C.: Armed Forces Institute of Pathology; 1991.

45. Casso EM, Grin-Jorgensen CM, Grant-Kels JM. Spitz nevi. J Am Acad Dermatol 1992;27:901-13.

46. LeBoit PE. Simulants of malignant melanoma. A rogue's gallery of melanocytic and nonmelanocytic imposters. In: LeBoit PE, editor. Pathology: state of the art reviews. Vol. 2, No. 2. Malignant melanoma and melanocytic neoplasms. 1st ed. Philadelphia: Hanley and Belfus; 1994. p. 195-258.

47. McCalmont TH. The clinical context: A tool for fine-tuning objective histologic diagnosis of cutaneous pigmented lesions. In: LeBoit PE, editor. Pathology: state of the art reviews. Vol. 2, No. 2. Malignant melanoma and melanocytic neoplasms. 1st ed. Philadelphia: Hanley and Belfus; 1994. p. 143-80.

48. Brinck U, Gabius HJ, Zeng FY, Gerke V, Lazarou D, Zografakis C, et al. Differential expression of calcyclin and its accessible ligands in various types of cutaneous tumors. J Dermatol Sci 1995;10:181-90.

49. Ilg EC, Schafer BW, Heizmann CW. Expression pattern of S100 calcium-binding proteins in human tumors. Int J Cancer 1996;68:325-32.

50. Fullen DR, Headington JT. Factor XIIIa-positive dermal dendritic cells and HDL-DR expression in radial versus vertical growth-phase melanomas. J Cutan Pathol 1998;25:553-8.

51. Donato R. Functional roles of the S100 proteins, calciumbinding proteins of the EF-hand type. Biochim Biophys Acta 1999;1450:191-231.

52. Komatsu K, Kobune-Fujimara Y, Andoh A, Ishiguru S, Hunai H, Suzuki N, et al. Increased expression of S100A6 at the invading fronts of the primary lesion and liver metastasis in patients with colorectal adenocarcinoma. Br J Cancer 2000;83:769-74.
53. Stulik J, Osterreicher J, Koupilova K, Knizek J, Bures J, Jandik $\mathrm{P}$, et al. Differential expression of the $\mathrm{Ca} 2+$ binding S100A6 protein in normal, preneoplastic and neoplastic colon mucosa. Eur J Cancer 2000;36:1050-9.

54. Stradal TB, Gimona M. Ca (2+)-dependent association of S100A6 (calcyclin) with the plasma membrane and the nuclear envelope. J Biol Chem 1999;274:31593-6.

55. Fullen D, Reed J, Finnerty B, McNutt NS. S100A6 preferentially labels type $\mathrm{C}$ nevus cells and nevic corpuscles: additional support for schwannian differentiation of dermal nevi. J Cutan Pathol 2001;28:393-9.

56. Fullen DR, Reed JA, Finnerty B, McNutt NS. S100A6 expression in fibrohistiocytic lesions. J Cutan Pathol 2001;28:22934.

57. Loftus B, Loh LC, Curran B, Henry K, Leader M. Mac387: its non-specific as a tumour marker or marker of histiocytes. Histopathology 1991;19:251-5.

58. Gabrielsen TO, Brandtzaeg P, Hoel PS, Dale I. Epithelial distribution of a myelomonocytic antigen L1 in relation to cutaneous malignancies and melanocytic naevi. Br J Dermatol 1988;118:59-67.

59. McNutt NS, Finnerty B. S100A protein expression reflects the degree of atypia in nevi with architectural disorder. Virchows Arch 1999;435:311.

60. McNutt NS, Finnerty B. S100A protein expression reflects the grade of atypia in nevi with architectural disorder. J Cutan Pathol 1999;26:459.

61. McNutt NS, Reed JA, Murry T, Finnerty B. The antibody MAC387 detects S100A proteins in keratinocytes adjacent to melanoma in situ. Mod Pathol 1999;12:60.

62. Sherstha P, Muramatsu Y, Kudeken W, Mori M, Takai Y, Ilg $\mathrm{EC}$, et al. Localization of Ca2+-binding S100 proteins in epithelial tumors of the skin. Virchows Arch 1998;432: 53-9. 